\title{
POKONYWANIE PRZESZKÓD WODNYCH WEDŁUG STANDARDÓW NATO
}

\author{
W artykule przedstawiono klasyfikację przeszkód wodnych pod kątem trudności \\ ich pokonywania za pomocą wojskowego sprzętu przeprawowo- mostowego. Za- \\ prezentowano 3 rodzaje tego sprzętu: \\ - zmechanizowane mosty towarzyszące ( ZMT ); \\ - samobieżne i przewożone parki pontonowe (promy i mosty pływające); \\ - mosty składane (MS) \\ oraz możliwości ich zastosowania w zależności od potrzeb.
}

Słowa kluczowe: przeszkody wodne, mosty towarzyszące, mosty pływające, mosty składane

\section{Koncepcje pokonywania przeszkód wodnych przez wojska}

Pokonywanie przeszkód wodnych należy traktować jako nieodłączną, a zarazem skomplikowaną, część działań zaczepnych. Stopień trudności jest dlatego tak wysoki, ponieważ przeszkody wodne posiadają wiele atrybutów, które należy rozpatrywać jednocześnie. Należą do nich:

- szerokość i głębokość przeszkody wodnej;

- prędkość prądu wody;

- rodzaj gruntu dna i brzegów;

- ukształtowanie brzegów i ich rozbudowa;

- dojazdy do przeszkody wodnej, a także;

- możliwość obrony brzegu przeciwległego przez przeciwnika.

Klasyfikację przeszkód wodnych przedstawiono na rys. 1., a czynniki wpływające na ich pokonanie na rys. 2 .

\footnotetext{
${ }^{1}$ Janusz Szelka, Uniwersytet Zielonogórski, Instytut Budownictwa, Zakład Dróg i Mostów, ul. Szafrana 1, 65-516 Zielona Góra; tel.605581940; j.szelka@interia.pl
} 


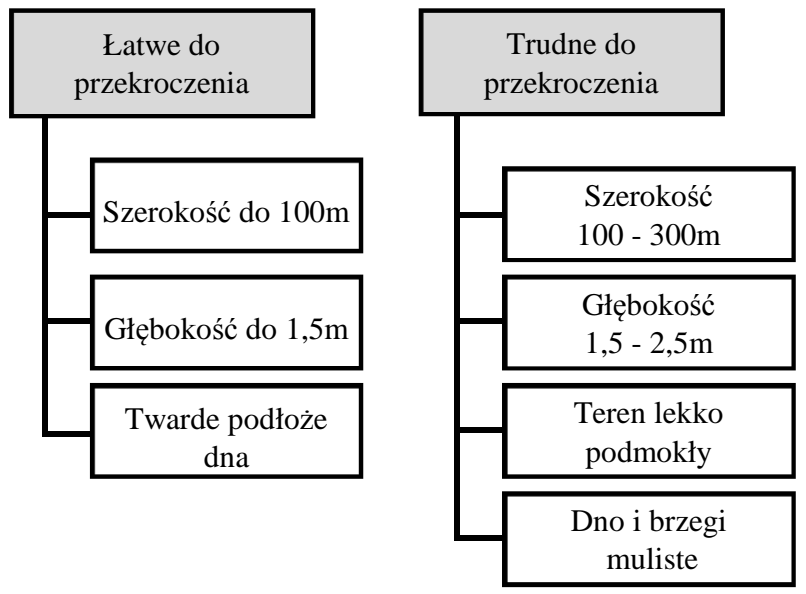

Rys. 1. Klasyfikacja przeszkód wodnych

Fig. 1. The classification of water obstacles

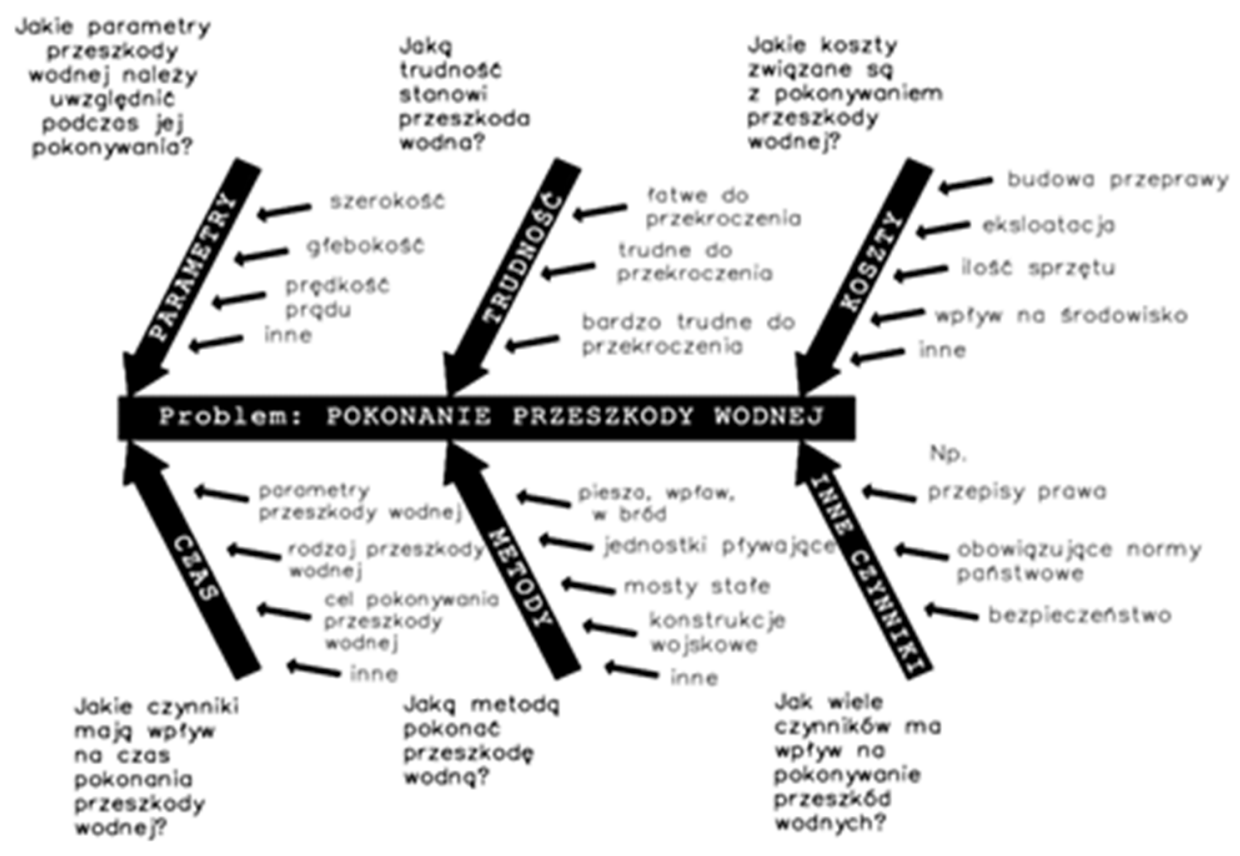

Rys. 2. Czynniki wpływające na pokonanie przeszkody wodnej

Fig. 2. The factors affecting the crossing of a water obstacle

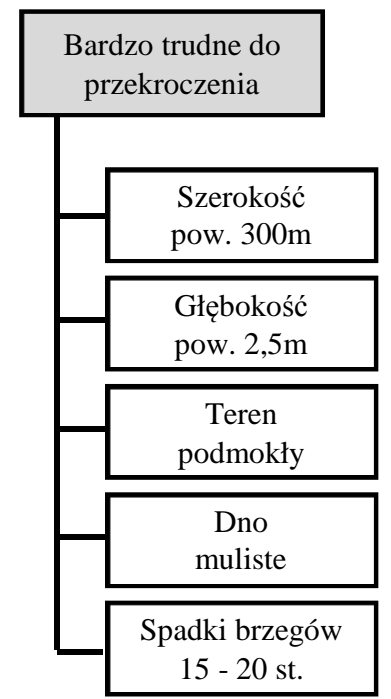


Pokonywanie przeszkód wodnych przez wojska może odbywać się:

- w warunkach bezpośredniego oddziaływania ogniowego przeciwnika (przekraczanie-forsowanie);

- przy braku tego oddziaływania (pokonywanie - przeprawa).

Forsowanie (rys. 3.), realizowane jest w trzech zazębiających się etapach [5]:

1) szturm - wykonywany jest w celu opanowania pozycji przeciwnika po drugiej stronie przeszkody wodnej. Głównym zadaniem szturmu jest uchwycenie brzegu i stworzenie warunków do przekroczenia przeszkody wodnej przez oddziały I rzutu związku taktycznego (ZT). W czasie forsowania z marszu szturm prowadzi oddział wydzielony (OW).

2) rozbudowa (opanowanie przyczółka) - to przedsięwzięcia realizowane na przyczółku po zakończeniu szturmu do czasu przekroczenia przeszkody wodnej przez siły główne.

3) koncentracja (umocnienie przyczółka) - to działania mające na celu wzmocnienie uderzenia na najdogodniejszym kierunku w rejonie przekraczania przeszkody wodnej.

Oczywiście, nie można negować faktu, że niektóre nowoczesne wozy bojowe i środki transportowe armii państw NATO, posiadają zdolność pokonywania brodów (np. Leopard 2 do głębokości 2,2 m, a transporter Marder do 2 m), czy pokonywania przeszkody pod wodą (czołg Leopard 2 - do $4 \mathrm{~m}$ ), jednak ich ilość na wyposażeniu tych wojsk jest niewystarczająca w stosunku do potrzeb.

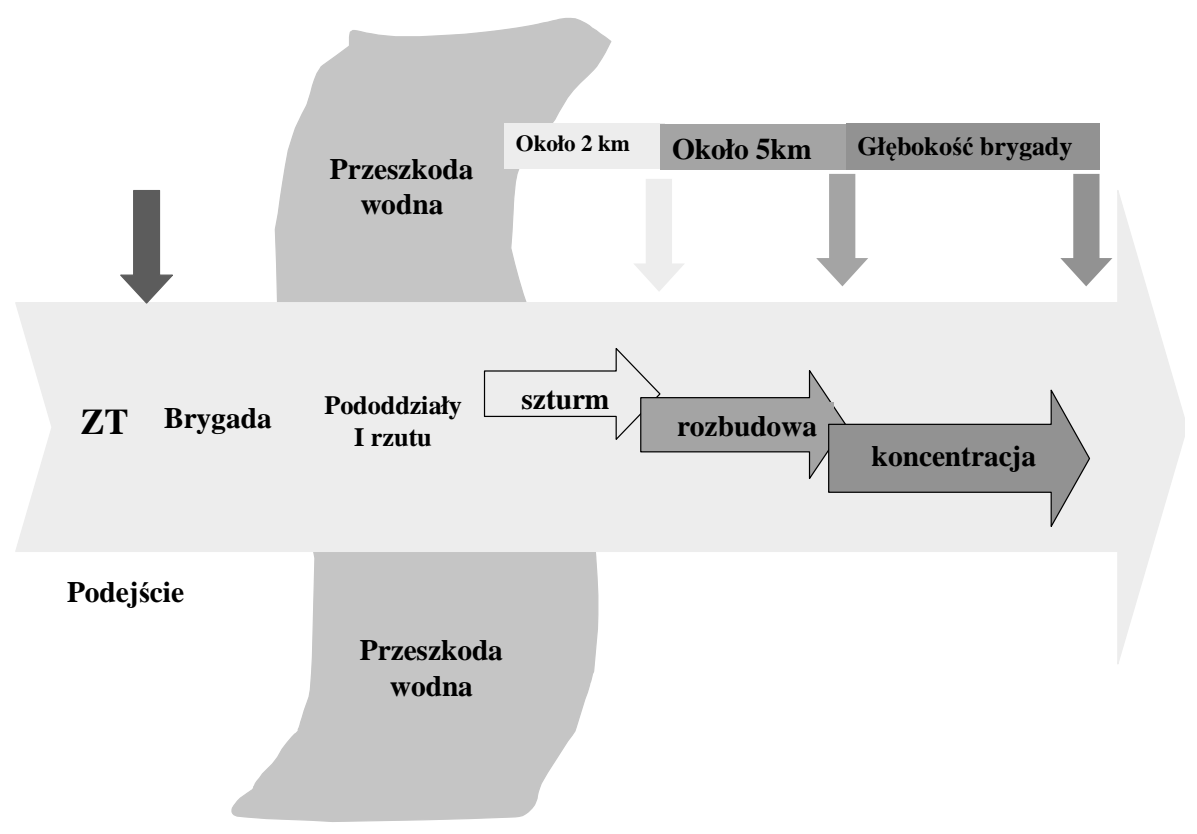

Rys. 3. Forsowanie przeszkody wodnej, na podstawie [5]

Fig. 3. The crossing of a water obstacle, based on [5] 
Analiza przeprowadzonych wielu ćwiczeń z wojskami doprowadziła do konkluzji, iż bardziej opłacalne jest zrezygnowanie $\mathrm{z}$ wysokiego tempa manewrowości wodnej ${ }^{2}$ pojazdów bojowych i transportowych na rzecz wyposażenia wojsk inżynieryjnych w specjalistyczne pojazdy i mosty, które będą stanowić dopełnienie szerokiego spektrum możliwości taktycznych wojsk. Dlatego też duże znaczenie w działaniach militarnych przypada wojskom inżynieryjnym, które poprzez budowę przepraw mogą stworzyć dowódcom pododdziałów liniowych i dużych związków taktycznych możliwości wyboru dogodnego miejsca do prowadzenia działań - niezależnie od przeszkód - aby utrzymać lub stworzyć siłę uderzeniową i manewrowość wojsk własnych.

Stosownie do liczby środków przeprawowych i założonego wariantu pokonania przeszkody wodnej urządza się główne i zapasowe przeprawy [5, 4]:

- w bród i wpław;

- po lodzie;

- pod wodą;

- desantowe;

- promowe;

- mostowe.

W pierwszej kolejności organizuje się i urządza przeprawy w bród i czołgów pod wodą oraz desantowe i promowe, których głównym zadaniem jest przeprawienie rzutu szturmowego a następnie przeprawy mostowe budowane dla przeprawienia sił głównych.

W zależności od zasad użycia wyróżnia się:

- mosty pola walki - do bezpośredniego wsparcia (towarzyszące i pływające);

- mosty II rzutu - do zapewnienia zaopatrzenia logistycznego (składane).

Ponadto, planując w warunkach bojowych budowę danego typu mostu czy rodzaju przeprawy, należy brać pod uwagę możliwość rozpoznania tych obiektów, a tym samym możliwość ich zniszczenia przez przeciwnika w krótkim czasie (do 1 godziny). Przyjmując, jako zasadę, dużą efektywność niszczenia obiektów mostowych, należy przewidywać dezorganizację działań wojsk i dużą pracochłonność odbudowy przepraw. Dlatego, aby zabezpieczyć przeprawy przed zniszczeniem lub uszkodzeniem, należy:

- ograniczyć do minimum czas urządzania przeprawy;

- przeprawiać w krótkim czasie możliwie największą liczbę sił i środków, oraz

- jak najszybciej dokonać manewru przeprawą (zwinięcie przeprawy, przemieszczenie jej w inne miejsce lub przejście na inny typ przeprawy).

Pełne i efektywne spełnienie tych wymagań jest możliwe jedynie przy sprzęcie przeprawowo-mostowym nowych generacji. Potwierdza to analiza sprzętu mostowego będącego na wyposażeniu armii wysoko uprzemysłowionych krajów świata, a zwłaszcza prowadzenie intensywnych prac nad doskonaleniem istniejącego oraz opracowywaniem i wprowadzaniem do wojsk - nowego sprzętu.

${ }^{2}$ Manewrowość wodna -to zdolność pojazdów do brodzenia, pływania bądź pokonywania przeszkód po dnie. 


\section{Sprzęt przeprawowo-mostowy państw NATO}

Zdaniem specjalistów NATO do pokonywania przez wojska przeszkód wodnych niezbędne są 3 typy podstawowych środków przeprawowo-mostowych:

1) zmechanizowane mosty towarzyszące - przeszkody wąskie do 50 metrów;

2) promy i mosty pływające (budowane z samobieżnych amfibii i parków pontonowych), oraz

3) mosty składane - przeszkody wodne średnie(do 150m) i szerokie(150-300m).

Wymaga się, aby nośność tych konstrukcji zapewniała przeniesienie obciążeń klasy MLC 70 - Military Load Class (obciążenie gąsienicowe - $700 \mathrm{kN}$ ) i MLC 100 (obciążenie kołowe ciągnikiem z czołgiem na przyczepie - $1000 \mathrm{kN}$ ).

\subsection{Zmechanizowane mosty towarzyszące}

W grupie zmechanizowanych mostów towarzyszących można wyróżnić mosty na podwoziu czołgów bojowych (AVLB, BIBER, HAB, MBS) i na podwoziu kołowym (LAB, LEGUAN 42, DoFB). Pierwsze z nich służą do przeprawy czołgów przez wąskie przeszkody w rejonie działań bojowych, drugie przewidziano do przeprawienia oddziałów i pododdziałów II rzutu.

Najnowszym przedstawicielem pierwszej grupy sprzętu mostowego jest Modułowy System Mostowy (MBS - Modular Bridge System). MBS przedstawiony na rys. 4., to nowa generacja zmechanizowanych mostów modułowych, $\mathrm{z}$ rodziny mostów LEGUAN produkowanych w Niemczech przez MAN Technologie AC. Ta grupa sprzętu mostowego spełnia wymagania taktyczne i operacyjne formacji pancernych w zakresie ich szybkiego przemieszczania się na polu walki.

Podstawowe dane techniczno-eksploatacyjne mostu:

- 3 moduły mostowe po 9,7 m każdy pozwalają na budowę mostu o długości 9,7 m, 18,7 m, 27,7 m i szerokości 4,0 m;

- masa modułu mostowego - $5000 \mathrm{~kg}$;

- nośność: MLC 70 - dla pojazdów gąsienicowych i MLC 100 - dla pojazdów kołowych;

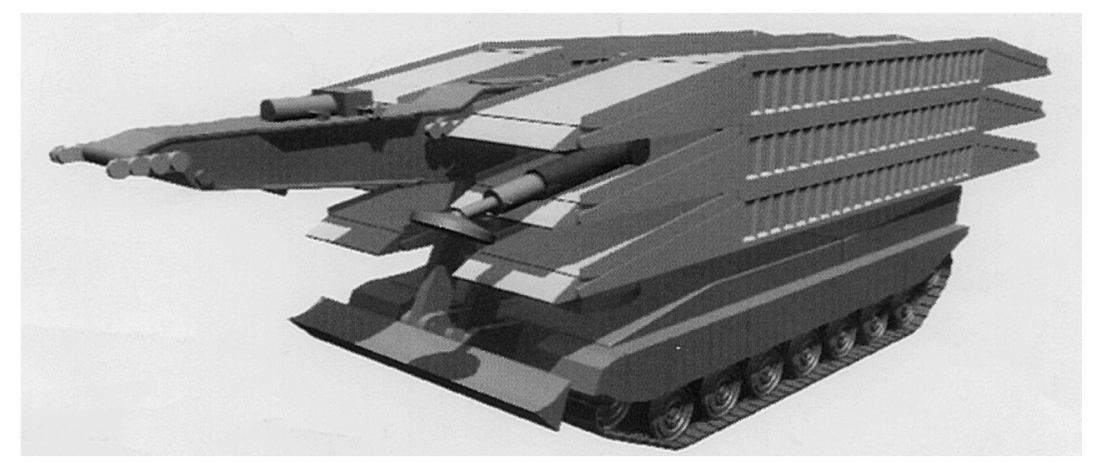

Rys. 4. MBS - Modułowy System Mostowy [3]

Fig. 4. MBS - A Modular Bridge System [3] 
- czas układania przez dwuosobową obsługę - 3 do 6 minut;

- całkowita masa ok. $61500 \mathrm{~kg}$ (most złożony z trzech modułów i podwozia Leopard 2).

Najnowsza wersja zmechanizowanego mostu składanego na podwoziu kołowym firmy Eurobrigde to DoFB - rys. 5 a) i b), o nośności do 1100 kN. Komplet mostu o długości do $46 \mathrm{~m}$ (podstawowa długość - $40 \mathrm{~m}$ ) i szerokości jezdni 4,4 $\mathrm{m}$ jest układany na przeszkodzie terenowej w ciągu 60 minut przez załogę w składzie 5-6 żołnierzy. Prędkość pojazdów gąsienicowych i kołowych po moście przyjmuje się do $25 \mathrm{~km} / \mathrm{h}$.

Do ciekawszych rozwiązań zmechanizowanych mostów towarzyszących należy zaliczyć brytyjski system mostowy BR 90, o klasie nośności MLC 70, z możliwością pokonywania przeszkód wodnych o szerokości od 9 do 60 m [6].

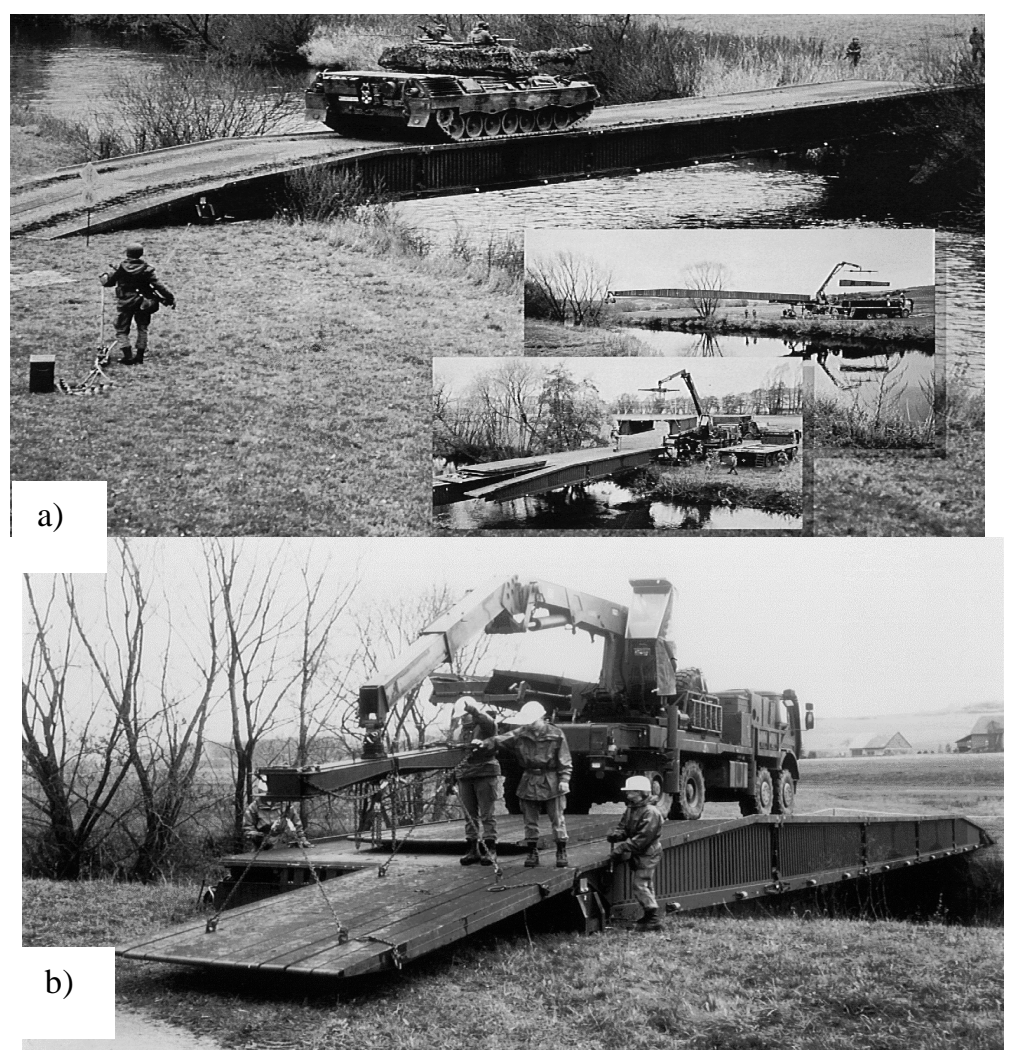

Rys. 5. Most DoFB [1]: a) całość mostu i fazy montażu, b) wykonywanie wjazdu na most

Fig. 5. The DoFB bridge: a) the whole bridge and stages in its assembly, b) making an entry for the bridge 


\subsection{Promy i mosty pływające}

Samobieżne i przewoźne parki pontonowe umożliwiają wojskom pokonywanie szerokich przeszkód wodnych poprzez wykonywanie mostów pływających i promów.

Do najnowocześniejszych samobieżnych środków przeprawowych można zaliczyć park mostowo-przeprawowy M3 (rys. 6a), produkowany przez niemiec ką firmę EWK (Eisenwerke Kaisers-Lautern GmbH). Park M3, wykonany jest ze stopów aluminium z jezdnią dostosowaną do pojazdów gąsienicowych i kołowych o klasie obciążenia odpowiednio MLC 70 i MLC 100.

Istotne zalety tego sprzętu to:

- czas budowy mostu o długości 100 m i szerokości użytkowej 4,76 m (składający się z 8 amfibii M 3) nie przekracza 20 minut przy 24-osobowej załodze; - możliwość budowy promów o szerokości jezdni 4,76 m:

- podwójnego - o klasie obciążenia MLC 70 dla pojazdów gąsienicowych,

- potrójnego - o klasie obciążenia MLC 100 dla pojazdów kołowych lub o masie 2x60 t dla pojazdów gąsienicowych;

- możliwość budowy przepraw przy prędkości prądu rzeki do $3,5 \mathrm{~m} / \mathrm{s}$;

- przepustowość mostu wynosi 250 pojazdów gąsienicowych na godzinę, przy minimalnej odległości między nimi - $20 \mathrm{~m}$.

Amfibia M3 pływa przy minimalnej głębokości 1,2 m, za pomocą hydrodynamicznego napędu strugowodnego. Posiada specjalne najazdy podtrzymywane hydraulicznie, a także żuraw do rozkładania odcinków brzegowych (ramp o długości $8,35 \mathrm{~m}$ każda), sterowany z kabiny kierowcy lub ze stanowiska na zewnątrz. Resorowanie pojazdu jest pneumatyczne, a zawieszenie kół niezależne. Ponadto pojazd posiada hydrauliczne urządzenie do wyciągania podwozia, które umożliwia jego szybsze wysuwanie i wciąganie. Dzięki temu urządzeniu uzyskuje się mniejszy opór $\mathrm{w}$ wodzie oraz większy prześwit w czasie jazdy w terenie. Pojazd o masie $25300 \mathrm{~kg}$ i parametrach $(12,9 \times 3,35 \times 3,90) \mathrm{m}$ oraz promieniu skrętu 23,4 m, ma także możliwość zmiany ciśnienia w oponach podczas jazdy, dzięki czemu dostosowuje się do podłoża.

W ostatnich latach firmy niemieckie Krupp Industrietechnik i MAN przystąpiły do badań i produkcji nowego mostu pontonowego typu wstęga o nazwie Folding Float Bridge 2000 - FSB 2 (rys. 6b), wykorzystując ideę konstrukcji amerykańskiego mostu Ribbon Bridge i jego niemiecką wersję FSB Aln. Szczególną zaletą mostu jest możliwość pokonywania wysokich brzegów - 2,2 m nad poziomem wody, dzięki sterowanym hydraulicznie rampom brzegowym. Jest łatwy do manewrowania na wodzie i w czasie wodowania. Rozkładanie członu następuje automatycznie podczas wodowania. Promy i mosty zbudowane z FSB 2 mogą być eksploatowane przy szybkości prądu wody do $3,5 \mathrm{~m} / \mathrm{s}$, i minimalnej głębokości rzeki 1,2 m.

Prom może być montowany z dwóch ramp o długości 7,5 $\mathrm{m}$ i potrzebnej liczby sekcji środkowych o długości 6,7 m każda. Gdy składa się on z dwóch ramp i dwóch sekcji środkowych, może być obciążony do MLC 70. 


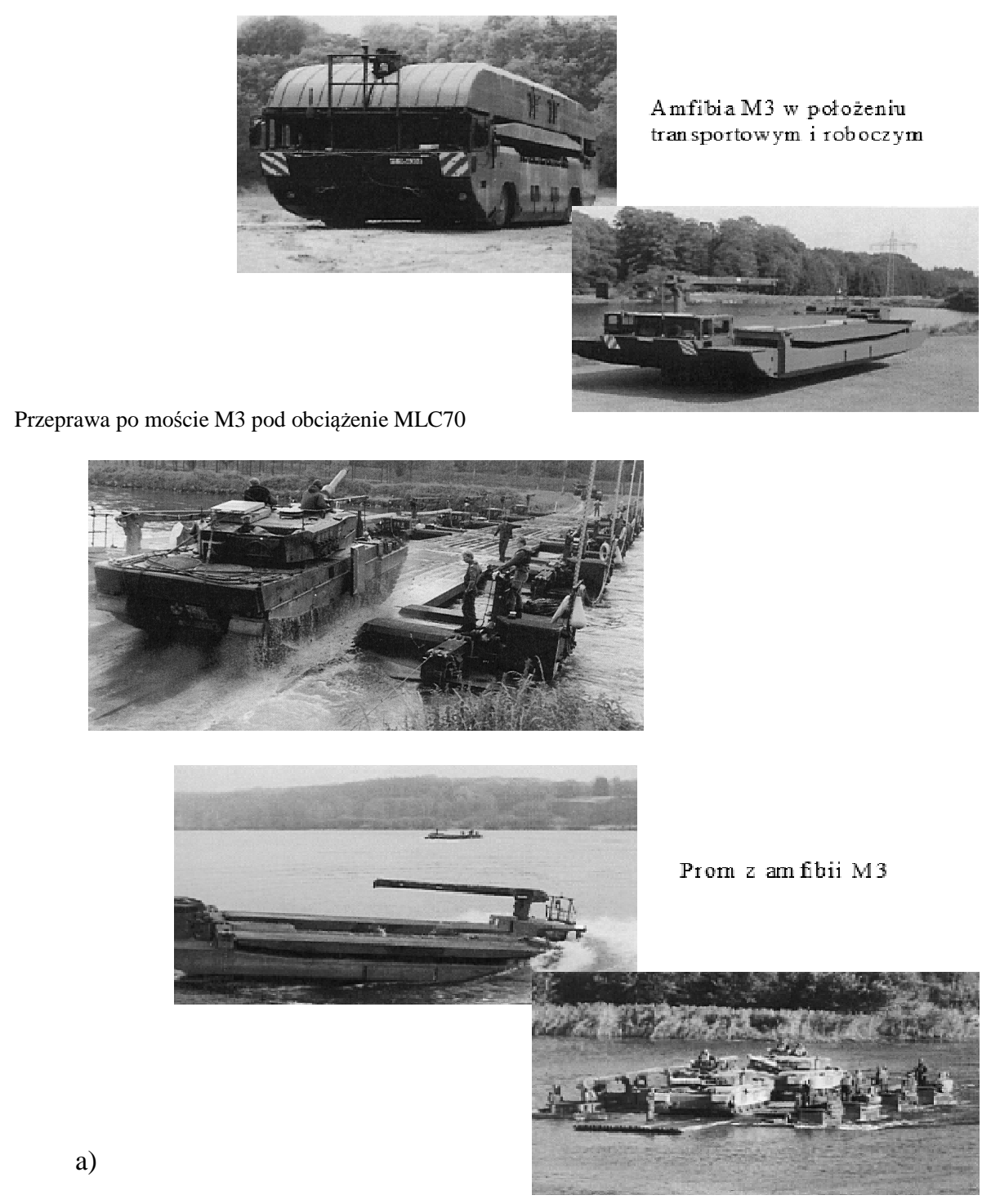

Rys. 6. Promy i mosty pływające: a) z konstrukcji M3 b) z konstrukcji FSB2 [3]

Fig. 6. Ferries, and a) M3 and b) FSB2 amphibious rigs 


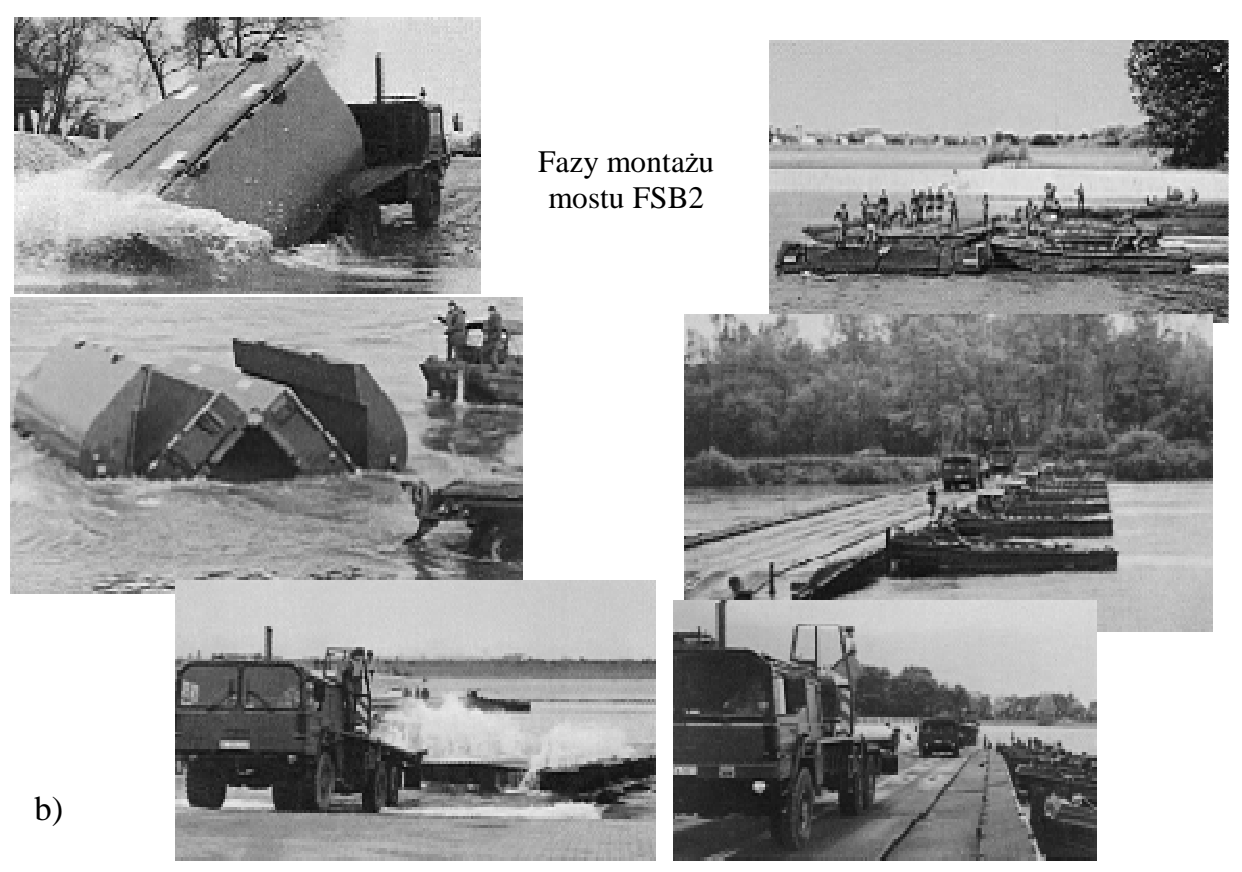

Rys. 6 (cd.). Promy i mosty pływające: a) z konstrukcji M3 b) z konstrukcji FSB2 [3]

Fig. 6 (cont.). Ferries, and a) M3 and b) FSB2 amphibious rigs

Do budowy mostu o długości $100 \mathrm{~m}$ potrzeba 60 minut. Szerokość użytkowa mostu jezdni wynosi $4,1 \mathrm{~m}$, a chodników $(2 \times 2,22) \mathrm{m}$. Most ma przepustowość 200 pojazdów MLC 70 na godzinę.

\subsection{Mosty składane (MS)}

Budowa mostów i wiaduktów stanowi istotne ogniwo w systemie przygotowania i utrzymania dróg manewru, dowozu i ewakuacji. Ważną rolę w wykonaniu tego zadania spełniają mosty składane na podporach stałych lub pływających. Niejednokrotnie warunki terenowe (skaliste suchodoły, urwiste brzegi, itp.) pozwalają na budowę wyłącznie mostów składanych. Służą one głównie do zabezpieczenia przegrupowania drugich rzutów związków operacyjnych i odwodów oraz odbudowy zniszczonych mostów stałych.

Rozwój MS ukierunkowany jest głównie na wprowadzenie zmian konstrukcyjnych i technologicznych mostów już istniejących, jak też organizacji ich budowy poprzez stosowanie nowoczesnych, bardziej wytrzymałych i lekkich materiałów czy też reorganizacji montażu. Pozwala to w efekcie zwiększyć zarówno rozpiętość przęsła i jego nośność, jak też skrócić ogólny czas budowy przeprawy. 
Powszechny sposób budowy tego typu mostów, to montowanie konstrukcji nośnej na brzegu wyjściowym i stopniowe jej wysuwanie na przeszkodę terenową. W zależności od długości mostu stosowane są podpory pośrednie (stałe lub pływające) lub wyłącznie podpory brzegowe (przy budowie mostów jednoprzęsłowych).

Na rys. 7 a) i b) zaprezentowano możliwości budowy mostów z wykorzystaniem najnowszych konstrukcji składanych MGB i Bailey’a o nośności MLC 60(70).

Most MGB o rozstawie dźwigarów 4,6 m znajduje się aktualnie na wyposażeniu armii wielu państw NATO, Do jego zalet zaliczyć można:

- lekkość konstrukcji (stopy aluminium, cynku i magnezu) pozwalająca na montaż ręczny konstrukcji przęsłowej mostu;

- stosowanie typowych podpór ( słupy z odcinków $3 \mathrm{~m}$ ) o dopuszczalnej wysokości $28 \mathrm{~m}$ na lądzie i $12 \mathrm{~m}$ - w wodzie;

- łatwość transportu konstrukcji MGB w paletach o wymiarach $(6,0 \times 2,4 \times 2,4) \mathrm{m}$;

- możliwość wykorzystania MGB w paletach do budowy mostów pływających.

Układy konstrukcyjne mostu MGB przedstawia poniższa tabela.

Tabela 1. Układy konstrukcyjne mostu MGB

Table 1. MGB Bridge construction systems

\begin{tabular}{|c|c|c|c|c|c|}
\hline TYP & $\begin{array}{l}\text { Klasa } \\
\text { [MLC] }\end{array}$ & $\begin{array}{l}\text { Długość } \\
\text { [m] }\end{array}$ & $\begin{array}{c}\text { Zespół } \\
\text { budujący } \\
\text { [szt] }\end{array}$ & $\begin{array}{c}\text { Czas } \\
\text { budowy }\end{array}$ & $\begin{array}{c}\text { Transport } \\
\text { w paletach } \\
\text { po } 4000 \mathrm{~kg} \\
\text { [szt] }\end{array}$ \\
\hline Jednopiętrowy & $\begin{array}{l}60 \\
16\end{array}$ & $\begin{array}{c}9 \\
22\end{array}$ & $\begin{array}{c}9 \\
17\end{array}$ & $\begin{array}{l}15^{\prime} \\
30^{\prime}\end{array}$ & $\begin{array}{l}2 \\
5\end{array}$ \\
\hline Dwupiętrowy & $\begin{array}{l}60 \\
16 \\
\end{array}$ & $\begin{array}{l}30 \\
49\end{array}$ & $\begin{array}{l}25 \\
25\end{array}$ & $\begin{array}{l}45^{\prime} \\
90^{\prime}\end{array}$ & 10 \\
\hline $\begin{array}{l}\text { Dwa przęsła + } \\
\text { filar }\end{array}$ & 60 & 51 & 40 & $3 \mathrm{~h}$ & 20 \\
\hline $\begin{array}{l}\text { Trzy przęsła+ } \\
\text { filar }\end{array}$ & 60 & 76 & 40 & $6 \mathrm{~h}$ & 27 \\
\hline Wzmocniony & 60 & 49 & 32 & $2 \mathrm{~h}$ & 18 \\
\hline $\begin{array}{l}\text { Dwupiętrowy } \\
\text { most pływający }\end{array}$ & 60 & do 91,5 & \multirow{2}{*}{\multicolumn{3}{|c|}{$\begin{array}{l}\text { Liczba ludzi i czas budowy zależy od } \\
\text { długości budowanego mostu. }\end{array}$}} \\
\hline $\begin{array}{l}\text { Jednopiętrowy } \\
\text { most pływający }\end{array}$ & 60 & do 91,5 & & & \\
\hline
\end{tabular}




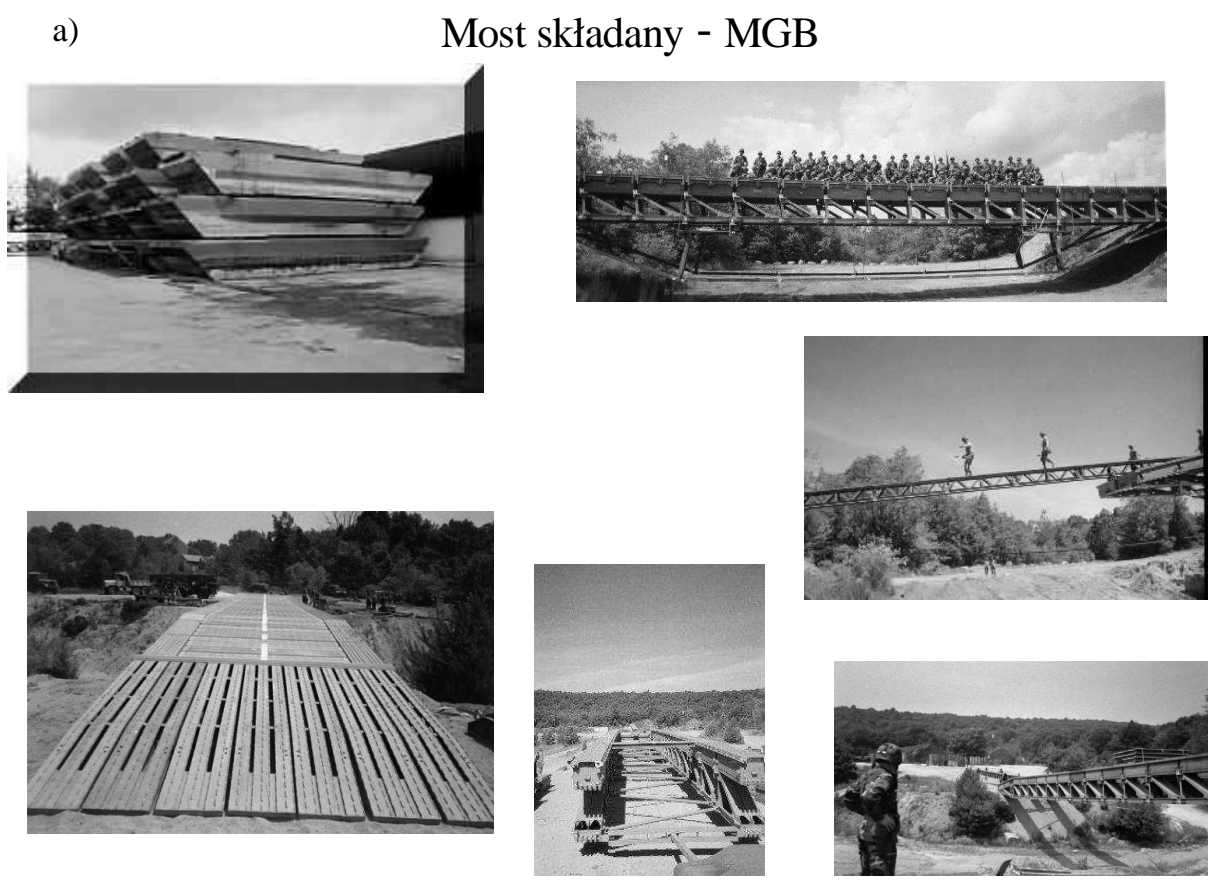

b) Most składany - Bailey

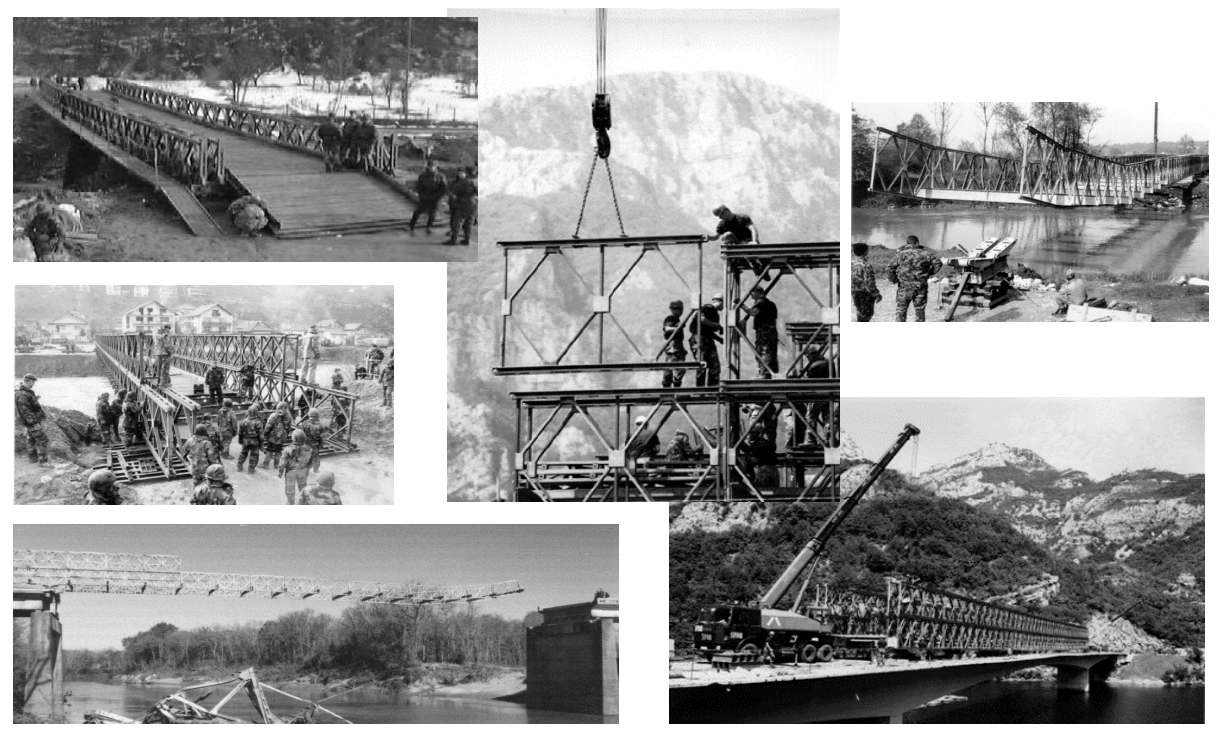

Rys. 7. Fazy montażu mostów składanych: a) MGB b) Bailey’a [2]

Fig. 7. The stages in the assembly of a) MGB and b) Bailey foldable bridges 
Najnowsze konstrukcje mostu składanego Bailey'a znane są po dwoma nazwami: Acrow i Mabey.

Acrow:

- udoskonalona wersja (stal spawalna o wysokiej wytrzymałości), co podwyższyło o $67 \%$ nośność na zginanie, ścinanie i ściskanie przy wyboczeniu;

- dwukrotnie wyższa sztywność ogólna i odporność na zniszczenie w stosunku do poprzedniej konstrukcji mostu;

- możliwość kształtowania jezdni dla ruchu jedno- i dwukierunkowego oraz zastosowania montażu ręcznego.

Mabey:

Przeznaczony do celów wojskowych i użyteczności publicznej:

- szerokość jezdni - 3,38 i 4,19 m - ruch jednokierunkowy,

$-6,1$ i 7,5 m-ruch dwukierunkowy;

$-9,1$ i $10,9 \mathrm{~m}$ - dla trzech pasm ruchu;

- składniki krat $(4,5 \times 2,36)$ m mają dwukrotnie wyższą wytrzymałość od Bailey'a standardowego;

- długość mostu: jednoprzęsłowy - 54 m; dwuprzęsłowy - 100m.

Montaż mostu obydwu wersji jest analogiczny jak w standardowym moście Bailey'a.

\section{Wnioski}

1) Przedstawione w artykule:

- zmechanizowane mosty towarzyszące (MBS, DoFB);

- promy i mosty zmontowane z samobieżnych amfibii M3 i konstrukcji FSB 2 oraz

- mosty składane MGB i Bailey'a

mogą być z dużym powodzeniem wykorzystywane do szybkiego pokonywania przeszkód wodnych .

2) Przeprawy (promy i mosty) budowane z tych konstrukcji:

- zapewniają przejazd wozów bojowych o dużej masie i przekroczonej skrajni drogowej;

- cechuje duża ruchliwość (szybkie przejście na przeprawy zapasowe), co stało się podstawowym zagadnieniem nowoczesnego pola walki.

3) Należy dążyć do wytworzenia własnego sprzętu mostowego przeznaczonego do szybkiego urządzania przepraw mostowych na wąskich przeszkodach wodnych, przewidzianych dla szczebla związku taktycznego [7].W założeniach projektowych należałoby preferować zmechanizowany most składany łączący w sobie cechy:

- klasycznego mostu składanego (modułowe elementy);

- zmechanizowanego mostu towarzyszącego (integralne urządzenia i mechanizmy do sprawnego montażu i układania konstrukcji na przeszkodzie przy małej liczebności zespołu obsługowego). 


\section{Literatura}

[1] Eurobridge, Mobile Briicken GmbH, D-88039 Fridrichshafen, Germany- Materiały poglądowe dotyczące DoFB.

[2] http://en.wikipedia.org/wiki/Bailey..bridge (dostęp: 25.01.2017r.).

[3] http://www.ewk.de (dostęp: 12.02.2017r.).

[4] NATO - Doktryna wojsk inżynieryjnych sił lądowych - ATP - 52, Norm. 16/98, Biuro Wojskowej Służby Normalizacyjnej MON, Warszawa 1998.

[5] Regulamin działań wojsk lądowych, DW Ląd 16/99, Warszawa 1999.

[6] Szelka J. Przewoźne mosty składane - brytyjski BR 90. Wojskowy Przegląd Techniczny i Logistyczny, nr 1/1998.

[7] Szelka J. Akwizycja wiedzy eksperckiej przy projektowaniu nowoczesnego sprzętu mostowego, IV Międzynarodowa Konferencja Naukowo-Techniczna nt.: Uzbrojenie i sprzęt inżynieryjny Sił Zbrojnych RP z uwzględnieniem interoperacyjności i kompatybilności ze standardami NATO w działalności naukowo-badawczej, WITI - Polanica Zdrój 28-29.04.1999.

\section{CROSSING WATER OBSTACLES IN ACCORDANCE WITH NATO STANDARDS}

\section{S u m m a r y}

The article presents the classification of water obstacles in terms of the difficulty with which they are crossed with military crossing and bridging equipment. It discusses three types of equipment:

- support bridges,

- self-propelled and transported pontoon parks (ferries and amphibious rigs),

- foldable bridges,

and their employment as needed.

Keywords: water obstacles, support bridges, pontoon parks, foldable bridges

Przestano do redakcji: 02.06.2017 r.

Przyjęto do druku: 01.09.2017 r. 